\title{
Exploring the Factors That Lead to a Positive Behavior in Indian Consumers Purchasing a Sustainable-Fuel Efficient Two Wheeler
}

\author{
Ruby Chanda, Vanishree Pabalkar, Tushar Mishra
}

\begin{abstract}
Purpose: INDIA ranked 177th out of 180 countries as per 2018 Environmental Performance Index depicting it one of the most polluted country in the world (The Hindu 2018). Recent research on environmental sustainability suggests that firms' engagement in green values, adoption of a proactive approach to climate change, and emphasis on sustainability are all driven by the need for a long-term competitive advantage.

Research approach: This research explores the attitude of the Indian consumers towards sustainability and its affect on their decision making when purchasing a two wheeler. Three hypotheses were proposed to identify the association between certain attitude related variables and intention of buying a two wheeler. The data collected was analyzed through factor analysis using IBM SPSS 20.
\end{abstract}

Findings: The results indicated an association between intentions of buying a fuel efficient two wheeler and attitude, perspective towards climate and willingness to change lifestyle. The study also revealed that three types of consumer segments exist. Firstly, the a ffect of attitude towards sustainability as a determinant of the purchase intention of a two wheeler. Of these three segments, two have a positive attitude towards sustainability and can be categorized as "Wannabe Sustainable" and "Active sustainable" who are aware of the ill-effects of using nonrenewable fuel based two wheelers and acknowledge the role of government and self. However, third segment turns out to be "sustainable ignorers" or "Indulgers".

Research Implications: Implications for marketers to concentrate on Indian consumers and more particularly the younger population for developing sustainability attitude and design a suitable strategy for marketing and product development in the two wheelers market.

Originality/Value: The study attempts to ascertain an insight into socially responsible purchase behavior of Indian consumers. It also presents a scope for future studies on consumer social responsibility in rural consumers of India.

Keywords: Sustainability, two wheelers, Consumers, attitude, purchase behavior.

\section{INTRODUCTION}

The non-renewable natural resources available on the planet earth are limited and the pace at which these resources are being consumed is growing at a very fast pace. Transportation sector is heavily dependent on the petroleum resources for its survival, as majority of the vehicles consume either petrol, diesel or compressed natural gas

Revised Manuscript Received on September 10, 2019.

Dr. Ruby Chanda, Symbiosis International (Deemed University), Pune, Maharashtra, India.

(Email: ruby.chanda@sims.edu)

Dr. Vanishree Pabalkar, Symbiosis International (Deemed University), Pune, Maharashtra, India.

(E-mail: vanishree.p@sims.edu)

Mr. Tushar Mishra, Symbiosis International (Deemed University), Pune, Maharashtra, India.

(E-mail: 14.tushar@gmail.com)
(CNG) / natural gas for powering their engines. Other than the exhaustion of these resources, there is a much graver problem that has risen due to the rapid consumption of these non-renewable petroleum resources, it is the increasing levels of air pollution that has led to the deteriorating health of people. Another issue that has become very important is the issue of climate change. The governments across the countries have taken a note of this trend and have built up a well-established structure that addresses this issue of pollution due the emissions from the commercial vehicles In India, the CPCB (Central Pollution Control Board), which comes under the Ministry of Environment, Forest and Climate Change, Government of India, sets the vehicular exhaust limits for both four and two wheelers. These limits are periodically revised to match with the global standards. All the vehicles are required to have a valid PUC (pollution under control) certificate, which indicates the vehicles emission levels and ensures that are within the set limits. The norms set by the CPCB have become stricter with time, the table below shows the change in two wheeler emission norms during the past few decades:

The two wheeler manufacturers have invested a lot in developing technologies and designs that lead to lesser emissions. Some of the important technologies used to reduce the emissions are: engine combustion controls, evaporative controls, catalyst technology, catalytic

converters, catalytic controls, fuel quality controls etc. (MECA Report, 2014)

Table 1: Evolution of emission standards in India

\begin{tabular}{|l|l|l|}
\hline Norms & $\mathbf{C O}(\mathbf{g} / \mathbf{k m})$ & $\mathbf{H C}+\mathbf{N O x})(\mathbf{g} / \mathbf{k m})$ \\
\hline 1991 Norms & $12-30$ & $8-12($ only HC) \\
\hline 1996 Norms & 4.5 & 3.6 \\
\hline $\begin{array}{l}\text { India stage } \\
2000 \text { norms }\end{array}$ & 2.0 & 2.0 \\
\hline $\begin{array}{l}\text { Bharat } \\
\text { stage-II }\end{array}$ & 1.6 & 1.5 \\
\hline $\begin{array}{l}\text { Bharat } \\
\text { Stage-III }\end{array}$ & 1.0 & 1.0 \\
\hline
\end{tabular}

Two wheeler emission norms

Thanks to the advancement in the field of ICT (information, communication and technology) during the last decade, the consumers today are much more informed, knowledgeable and conscious about the products and services they consume.We know that consumers consider various factors related to the product when they make a purchase decision and it becomes very important that the 
marketers understand these factors in depth so that they can better design and market their products and services.

In this study we have tried to analyze the sustainability factor of a two wheeler as an attribute while making the decision to purchase a bike.

\section{THEORETICAL BACKGROUND}

When it comes to consumers buying behavior or purchase intention, there are various factors that affect it. One of the factors that has been a point of study among scholars is green marketing (Denniset,, 2005). The attitude and behavior of the consumers has gone through a change in the past few decades due to increased awareness about the environment. Consumers now have a preference for products that are free of toxins and are environmentally friendly (Carrigan., 2005). The increased awareness among the consumers towards environment and sustainability led to the concept of green marketing. During the seventies the concept of environmental marketing picked up some heat and it was positively received by the consumers (Kassarjian, 1971), however it was only during the nineties that the concept started taking roots. This revolution has led to researchers spending time and effort in understanding the nature and aspirations of the so called green consumers (Medeiros and Ribeiro, 2013). Based on the various theories on consumer behavior the researchers have analyzed the sustainability or the environmental aspect of the consumption pattern and this has in turn motivated the businesses to act and appear such that they are seen as environment friendly, so that they can stay relevant in the market (Hansen, 2009). Most of the studies that have analyzed the behavior such as purchase intention or willingness to pay have been conducted in the developed regions of Europe or North America. The green attitude and behavior towards the purchasing is also being observed in the developing regions of Asian regions (Lee, 2009). Because of the rising levels and quality of education the green consumer market in India is also increasing (Singh, 2013). The studies in the Indian context have been done with few sectors like lodging and foods like genetically modified or organic foods (Chakrabarti, 2010).

The consumer's attitude in general has undergone a lot of change in the past few decades. Due to the availability of affordable communication and connectivity services consumers in the developing nations have also become aware of the impact their actions have on their surroundings. This development is even more relevant in the context of the consumers in the Asian region where most of the ancient philosophies were non materialistic and promoted the coexistence of humans and environment. There seems to be a union of the modern trend of consumerism and the traditional values of sustainability and environmental protection. A sub-branch of consumerism called eco consumerism, which is defined as a type of consumerism that expresses an affinity towards environment (Uusitalo 2004). There has been a clear shift from the materialistic inclination towards an optimistic view regarding the green products (Joseph-Mathews, 2009). When talking about the behavior of the consumers towards purchasing green product, it is related to the individual's perception about the environment and the consequences (Ramayah 2010). The purchase decision of the environmentally conscious consumers is influenced by two kinds of factors which are intrinsic and extrinsic factors. The intrinsic factors are the realization of individual's responsibility towards environment, inclination towards acquiring knowledge about the environment and understanding the impact of ones actions on the environment. The extrinsic factors are related to the general image of the individual in the social context and also to the various characteristics of the product. One of the key reasons for consumers to prefer green products is their attitude to support the protection of environment (Gadenne 2011). Some of the other important factors that affect the consumer's behavior towards the purchase of green product are: social appeal, environmental friendliness of the companies, experience with green products, drive towards environmental responsibility and support for environmental protection (Ghodeswar, 2015). The attitude and behavior resulting in purchase of a green product may be different with respect to different categories of products. It can depend on the level of consumers involvement in making the purchase decision, the cost associated with the product and also the trade-offs that have to be made to own a greener product.

\section{REVIEW OF LITERATURE}

India is the largest market for two wheelers in the world and this market continues to grow at a very fast pace. According to the Society of Indian Automobile Manufacturers (Siam) and the China Association of Automobile Manufacturer, India has left China behind and has become the world's largest market for two wheelers. In 2016 over 17.7 million units of two wheelers were sold in India as compared to 16.8 million units sold in China (Doval, 2017). One of the major reasons for this tremendous growth is the rise in number of female consumers for two wheelers. It was reported that around $35 \%$ of the customer base of Honda two wheelers in India are females.

With the growing economy and opportunities, the demand for mobility is also growing. However due to the comparatively low levels of income, high density of population and inappropriate transport infrastructure, like roads, owning a four wheeler is not a very feasible options for most of the Indians.

On the other hand the low cost and easy maneuverability of the two wheelers make it a very attractive options for most of the Indian households. It is very common to observe that most of the middle class Indian families that own a car also own at least one two wheeler. There is also a huge demand for two wheelers from the rural areas of India, and it can also be one of the important reasons for the fast track growth of this sector.The literature suggests that various factors influence the customer's decision to purchase a consumer durable. Studies have indicated that the demographic profile, source of information, buying habit etc play an important role in influencing the decision of the consumer (Juyal,2013). For two wheeler also, there are some important criteria's based on which the buying

Blue Eyes Intelligence Engineering 
decision is made. Studies have shown that some of the important factors for buying a two wheeler specially for females are: Physical fitment, economy, comfort, durability (Mundu,2011). Other than these factors, the attributes of the vehicle like style, weight, power, mileage, price, comfort, leg space and height are also very important (Mundu,2011).

Till now not many researchers have focused on the factors that influence the demand of sustainable and environmentally friendly products from the perspective of a consumer (Wang and Hazen, 2016). However, in the recent times the focus of researchers has also gone towards the sustainability factor associated with the vehicle. In the current study we are trying to find out the relevance of sustainability as a criteria for the Indian consumers when it comes to purchasing a two wheeler. The research question that we pose is wheeler when it comes to buying a fuel efficient two wheeler in India?

The study takes the Theory of reasoned action (TRA) as its base and explores the attitude and subjective norms that impacts the buying intention of the consumer and finally affecting their behavior. A company is a profit driven entity and would invest in sustainable products only if the consumers have a desire to consume it (Chan, 2016). There are consumers who also worry about the environmental impact that their two wheeler will have on the environment, they are aware of their carbon footprint and would want to take measures that help in reducing it. The studies have demonstrated that the attitude and perceived control have an impact on the purchase intention of the individuals. Attitude of an individual towards environment has a positive effect on the purchase intention while the perceived control has a negative impact on the purchase decision ( $\mathrm{Lu} \mathrm{Xu}, 2018$ ). Models like EAPIM (Environmental affect purchase intention model) which is a development over the Theory of planned behavior (TPB) have been proposed to demonstrate and analyze the importance of the environmental consideration of the consumers when making a purchase decision. ( $\mathrm{Lu} \mathrm{Xu}, 2018$ ). The EAPIM model does the evaluation of effect size and predictive relevance and indicates a large effect size of purchase intention (Cohen, 1988). Hence we have formulated our first hypotheses as:

H1: There is an association between attitude towards sustainability and the intention of buying a fuel efficient two wheeler.

The consumers today are much more aware of the impact that their actions have on the environment and this consciousness has played a very important role in shaping the behavior of the consumers worldwide. The segment of such environmentally conscious individuals is growing every year and hence this field has generated a lot of interest among the marketing researchers. Segmenting the customers based on values has been the focus of many researchers for past few decades. It has been assumed that values more closely related to behavior as compared to the personality traits. Based on values there is a type of behavior that is called "sustainable consumption" and the most committed consumers within this type are referred to as LOHAS (Lifestyle of health and sustainability) (Kreeb, 2008).
RQ: How relevant is the sustainability aspect of the two

The Natural Marketing Institute, in 2002 used the new segmentation models and it divided the market for the environmentally related products into various segments based on the attitude of the consumers towards sustainability, ethical consumption and environment. The market is accordingly divided into five segments: LOHAS, Naturalists, Drifters, Conventionalists and the Unconcerned. (French, 2006).

If the demographic profile of the LOHAS is considered we find that they are mostly women who are middle aged, married with no children. They are also formally employed with a decent salary and a college degree. (NMI report,2008). There have been studies to explain why people behave in a sustainable way, some indicate that a sustainable behavior can be explained by self-expression and identitycongruency (Fitzmaurice, 2005). The theory of reasoned action (TRA) in psychology attempts to establish the relationship between attitudes and behaviors (Ajzen \& Fishbein, 1980; Fishbein \& Ajzen, 1975). TRA states that the behavioral intention is based on the assumption or belief that behaving in a particular way will lead to a particular outcome. The beliefs that lead to a behavioral intention can be classified as either behavioral or normative. An individual's attitude towards performing a behavior is based on his or her behavioral beliefs and the subjective norms towards displaying a particular behavior depends on normative beliefs. (Fishbein \& Ajzen, 1975. Hence a certain aspects of the individual's attitude will make them more prone towards demonstrating a particular kind of behavior. Hence we have given our second and third hypotheses as:

$\mathrm{H} 2$ : There is an association between individual's perspective of the climate vs economic development debate and the intention of buying a fuel efficient or a sustainable two wheeler.

$\mathrm{H} 3$ : There is an association between willingness to change lifestyle for protecting environment and intention of buying a fuel efficient or a sustainable two wheeler.

The scientific literature suggests using factor analysis as a suitable approach for conducting such a type of normative empirical study (DiStefano, 2005). In our study we are focusing on how the sustainability attitude and sustainable behavior norms affect the behavioral intention of buying a fuel efficient two wheelers among the Indian consumers.

\section{METHODOLOGY}

To test the hypotheses a survey was designed with 15 questions that would allow us to measure the attitude of the respondents towards sustainability aspect of the two wheeler in particular and towards the concept of sustainability in general. Other than the 15 items mentioned the questionnaire also captured the demographic details of the respondents like age, gender and educational qualification.To test the awareness of the respondents on the subject of sustainability a four questions with true/false response were administered. The responses were then converted to the Likert scale for appropriate analysis. 


\section{A. Sample and Data Collection}

The 15 questioned survey was administered to 150 candidates and out of those 135 responded. The respondents mostly included individuals from the age range of 18 to 35 years old, who are the major consumers of two wheelers. All the respondents belonged to urban areas and were educated. All the questioned required responses on a 5 point Likert scale, which included responses from (totally agree, agree, neutral, disagree, totally disagree). To check the reliability of the questionnaire Cronbach Alpha test was conducted on the questionnaire using the IBM SPSS software.

\section{B. Hypotheses Testing}

The hypotheses were tested using Chi Square statistic for the sample that was surveyed. The null and the alternate hypotheses are as follows:

\section{Hypotheses 1}

H0: There is no association between attitude towards sustainability and the intention of buying a fuel efficient two wheeler.

H1: There is an association between attitude towards sustainability and the intention of buying a fuel efficient two wheeler.

\section{Hypotheses 2}

H0: There is no association between individual's perspective of the climate vs economic development debate and the intention of buying a fuel efficient or a sustainable two wheeler.

$\mathrm{H} 2$ : There is an association between individual's perspective of the climate vs economic development debate and the intention of buying a fuel efficient or a sustainable two wheeler.

\section{Hypotheses 3}

H0: There is no association between willingness to change lifestyle for protecting environment and intention of buying a fuel efficient or a sustainable two wheeler.

H3: There is an association between willingness to change lifestyle for protecting environment and intention of buying a fuel efficient or a sustainable two wheeler.

The variables used in the hypotheses: attitude, intention of buying, perspective towards climate, and willingness to change were measured through specific questions that were a part of the questionnaire. The responses taken from the respondents were on a Likert scale (an ordinal scale) however these responses were converted into nominal scale for hypotheses testing. The variables measured above were analyzed as binary categorical variables. Attitude was classified as positive/negative, intention of buying was classified as positive/negative, perspective towards climate as pro-climate/pro-economy and willingness to change lifestyle as willing/not willing.

The hypotheses were tested by applying Chi square, using the cross tabulation feature available on SPSS. The level of significance that we choose is alpha $=0.05$.

\section{Reliability}

The Cronbach Alpha value was 0.908, which is quite reasonable and validates the reliability of the questionnaire. After checking the reliability of the questionnaire the hypotheses were tested using chi square tests and Factor analysis was done on the 15 items using the IBM SPSS software and the results were analyzed to test the hypotheses.

\section{RESULTS}

A. Chi square test results

Result for Hypotheses 1

Table 2 : Chi square test result for Hypotheses 1

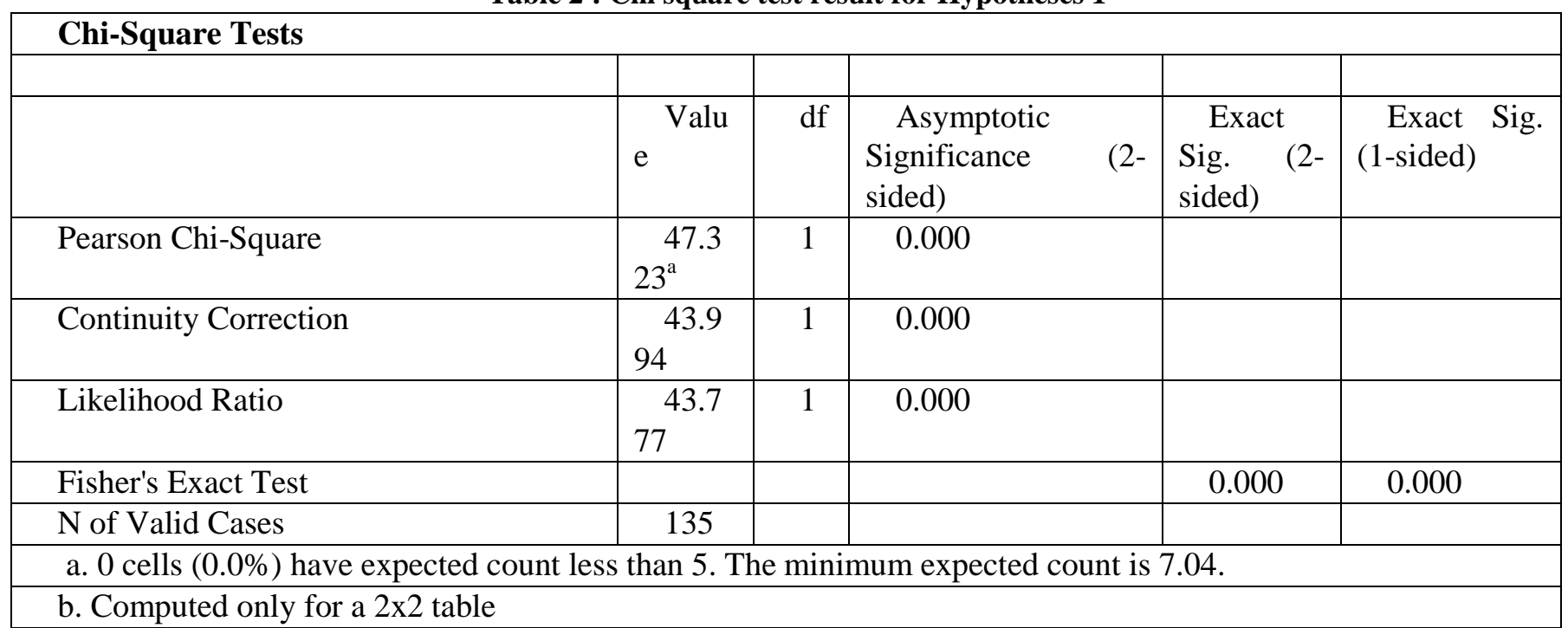

Association between attitude towards sustainability and the intention of buying a fuel efficient two wheeler. 
Table 3: Chi square test result for Hypotheses 2

\begin{tabular}{|c|c|c|c|c|c|}
\hline \multicolumn{6}{|l|}{ Chi-Square Tests } \\
\hline & $\mathrm{e}^{\text {Valu }}$ & $\mathrm{f}^{\mathrm{d}}$ & $\begin{array}{c}\text { Asymptotic } \\
\text { Significance } \\
\text { (2-sided) }\end{array}$ & $\begin{array}{l}\text { Exact } \\
\text { Sig. } \\
(2- \\
\text { sided })\end{array}$ & $\begin{array}{ccc}\begin{array}{c}\text { Exact } \\
\text { sided })\end{array} & \text { Sig. }\end{array}$ \\
\hline $\begin{array}{l}\text { Pearson Chi- } \\
\text { Square }\end{array}$ & $2^{31.36}$ & 1 & 0.000 & & \\
\hline $\begin{array}{l}\text { Continuity } \\
\text { Correction }\end{array}$ & $3^{29.15}$ & 1 & 0.000 & & \\
\hline Likelihood Ratio & $8^{30.53}$ & 1 & 0.000 & & \\
\hline $\begin{array}{l}\text { Fisher's Exact } \\
\text { Test }\end{array}$ & & & & 0.000 & 0.000 \\
\hline $\mathrm{N}$ of Valid Cases & 135 & & & & \\
\hline \multicolumn{6}{|c|}{$\begin{array}{l}\text { a. } 0 \text { cells }(0.0 \%) \text { have expected count less than } 5 \text {. The minimum expected count is } 13.06 \text {. } \\
\text { b. Computed only for a } 2 \times 2 \text { table }\end{array}$} \\
\hline
\end{tabular}

Association between individual's perspective of the climate vs economic development debate and the intention of buying a fuel efficient for a sustainable two wheeler.

Result for Hypotheses 3

Table 4: Chi square test result for Hypotheses 3

\begin{tabular}{|c|c|c|c|c|c|}
\hline \multicolumn{6}{|l|}{ Chi-Square Tests } \\
\hline & \multirow[t]{2}{*}{ Value } & \multirow[t]{2}{*}{ df } & \multirow{2}{*}{$\begin{array}{c}\text { Asymptotic } \\
\text { Significance (2-sided) }\end{array}$} & \multirow{2}{*}{\begin{tabular}{l}
\multicolumn{2}{c}{ Exact } \\
Sig. \\
sided $)$
\end{tabular}} & \multirow{2}{*}{$\underset{(1-\text { sided })}{\text { Exact }} \quad$ Sig. } \\
\hline & & & & & \\
\hline $\begin{array}{l}\text { Pearson Chi- } \\
\text { Square }\end{array}$ & $8^{a}$ & 1 & 0.000 & & \\
\hline $\begin{array}{l}\text { Continuity } \\
\text { Correction }\end{array}$ & $2^{59.17}$ & 1 & 0.000 & & \\
\hline Likelihood Ratio & $6^{54.63}$ & 1 & 0.000 & & \\
\hline Fisher's Exact Test & & & & 0.000 & 0.000 \\
\hline $\mathrm{N}$ of Valid Cases & 135 & & & & \\
\hline \multicolumn{6}{|c|}{ a. 0 cells $(0.0 \%)$ have expected count less than 5 . The minimum expected count is 5.81 . } \\
\hline b. Computed only fc & ra $2 \times 2$ tal & & & & \\
\hline
\end{tabular}

Association between willingness to change lifestyle for protecting environment and intention of buying a fuel efficient or a sustainable two wheeler.Based on the results obtained the null hypotheses is rejected as the $\mathrm{p}$ value is less than the significance level that we had chosen i.e. alpha $=$ 
Exploring the Factors That Lead to a Positive Behavior In Indian Consumers Purchasing a Sustainable-Fuel Efficient Two Wheeler

\section{B. Factor Analysis Results}

Table 5: Total Variance Explaine

\begin{tabular}{|c|c|c|c|c|c|c|c|c|c|}
\hline \multirow[b]{2}{*}{$\begin{array}{l}\text { Compon } \\
\text { ent }\end{array}$} & \multicolumn{3}{|c|}{ Initial Eigenvalues } & \multicolumn{3}{|c|}{$\begin{array}{c}\begin{array}{c}\text { Extraction Sums of Squared } \\
\text { Loadings }\end{array} \\
\end{array}$} & \multicolumn{3}{|c|}{$\begin{array}{ccc}\begin{array}{c}\text { Rotation Sums of } \\
\text { Loadings }\end{array} & & \\
\end{array}$} \\
\hline & Tota & \begin{tabular}{cc|}
$\%$ & of \\
Variance &
\end{tabular} & Cumulative & Tota & \begin{tabular}{cc|}
$\%$ & of \\
Variance
\end{tabular} & $\begin{array}{l}\text { Cumulativ } \\
\text { e } \%\end{array}$ & Total & $\begin{array}{|cc|}\% & \text { of } \\
\text { Variance } & \\
\end{array}$ & $\begin{array}{l}\text { Cumulati } \\
\text { ve } \%\end{array}$ \\
\hline 1 & 7.159 & 47.729 & 47.729 & $9^{7.15}$ & 47.729 & 47.729 & 4.468 & 29.790 & 29.790 \\
\hline 2 & 1.367 & 9.116 & 56.845 & $7^{1.36}$ & 9.116 & 56.845 & 3.734 & 24.894 & 54.684 \\
\hline 3 & 1.122 & 7.477 & 64.322 & $2^{1.12}$ & 7.477 & 64.322 & 1.446 & 9.638 & 64.322 \\
\hline 4 & 0.879 & 5.859 & 70.181 & & & & & & \\
\hline 5 & 0.755 & 5.031 & 75.212 & & & & & & \\
\hline 6 & 0.711 & 4.741 & 79.953 & & & & & & \\
\hline 7 & 0.610 & 4.066 & 84.018 & & & & & & \\
\hline 8 & 0.478 & 3.189 & 87.208 & & & & & & \\
\hline 9 & 0.425 & 2.831 & 90.039 & & & & & & \\
\hline 10 & 0.372 & 2.480 & 92.519 & & & & & & \\
\hline 11 & 0.316 & 2.106 & 94.625 & & & & & & \\
\hline 12 & 0.253 & 1.689 & 96.314 & & & & & & \\
\hline 13 & 0.213 & 1.418 & 97.732 & & & & & & \\
\hline 14 & 0.182 & 1.214 & 98.946 & & & & & & \\
\hline 15 & 0.158 & 1.054 & 100.000 & & & & & & \\
\hline
\end{tabular}

Rotated component matrix:

We can observe from the Total Variance Explained chart that a total of three

Table 6: Component reduction matrix

\begin{tabular}{|c|c|c|c|}
\hline & \multicolumn{3}{|c|}{ Component } \\
\hline & 1 & 2 & 3 \\
\hline $\begin{array}{l}\text { 1. Governments have a responsibility of controlling pollution levels but the common people are } \\
\text { also equally responsible for it. }\end{array}$ & 0.805 & & \\
\hline 2. More and more people should switch to e-bikes or other less polluting two wheeler. & 0.697 & 0.398 & \\
\hline It will be wise to invest in companies that are manufacturing more eco-friendly two wheeler. & 0.640 & 0.422 & \\
\hline Children should be taught more about the harmful effects of pollution and climate change. & 0.741 & 0.373 & 0.306 \\
\hline All government buses should be electric or should run on CNG(clean fuel) & 0.668 & 0.403 & \\
\hline Clean and sustainable environment is more important than fast paced industrial growth. & 0.312 & 0.745 & \\
\hline $\begin{array}{l}\text { 7. The industries that cause most pollution should be taxed heavily even if they contribute to the } \\
\text { economic development. }\end{array}$ & & 0.802 & \\
\hline 8. Government should implement stricter norms on emissions by the two-wheelers. & 0.438 & 0.477 & \\
\hline $\begin{array}{l}\text { 9. One should always renew the PUC certificate of the vehicle on time and not wait for it to } \\
\text { expire. }\end{array}$ & 0.809 & & \\
\hline $\begin{array}{l}\text { 10. One should get the PUC certificate for the vehicle because it is a good step towards controlling } \\
\text { air pollution and not just to escape the fine imposed by traffic police. } \\
11 \text {. I will prefer a bike that is fuel efficient and less polluting over a bike that has more power }\end{array}$ & 0.727 & $\begin{array}{c}0.401 \\
0.741\end{array}$ & \\
\hline $\begin{array}{l}12 . \\
\text { I will be ready to pay } 10 \% \text { more for a bike that is significantly less polluting but gives same } \\
\text { milemared to other bikes in the same category? }\end{array}$ & & 0.604 & \\
\hline 13. I would love to own a good looking stylish bike even if it is more polluting than other bikes. & & & 0.781 \\
\hline $\begin{array}{l}\text { 14. I will change my current lifestyle and compromise on luxury if it can help in protecting the } \\
\text { environment? }\end{array}$ & & 0.693 & 0.334 \\
\hline 15. How would rate your knowledge on the topic of sustainability? & 0.421 & & 0.518 \\
\hline
\end{tabular}




\section{DISCUSSION}

Based on the results of the chi-square tests conducted for the three proposed hypotheses, we can safely reject their respective null hypotheses. This leads to the acceptance of our proposed alternative hypotheses and establishessignificant association between a) attitude towards sustainability and the intention of buying a fuel efficient two wheeler, b) between individual's perspective of the climate vs economic development debate and the intention of buying a fuel efficient or a sustainable two wheeler and c) between willingness to change lifestyle for protecting environment and intention of buying a fuel efficient or a sustainable two wheeler.The results for factor analysis gave three components that had eigenvalues of more than 1. The three components were further analyzed and the appropriate description was given to them. Following is the detailed analysis of the three loaded components

Component 1: This component had high Pearson

correlation with the items 1, 4, 9 and 10. It also had

moderate correlation with the items 2,3 , and 5 . If we get into details of these items we have the following description:

Item 1: Attitude own responsibility towards sustainability

Item 2: Attitude towards e-bikes

Item 3: Faith in companies offering sustainable solutions

Item 4: Attitude towards sustainability awareness

Item 5: Attitude towards government's role

Item 9 and 10: Attitude towards government rules with respect to sustainability norms

The analysis of these items show us that those who belong to this component have a positive attitude towards the sustainability efforts. These are the people who are aware of the ill-effects of using non-renewable fuel based two wheelers, they also acknowledge the role of government and their own role in saving the planet by opting for a sustainable approach towards life.

However what they think does not reflect in their actions as they are not really keen in changing their lifestyles.

We can call this segment of consumers "Wannabe Sustainable".

Component 2: This component has high Pearson correlation with items $6,7,11$ and 14. It also has moderate correlation with items 8 and 12. The description of these items is as follows:

Item 6 and 7: Attitude towards trade of between economic development and climate change

Item 8: Strict rules by government

Item 11 and 12: Behavior towards purchasing a sustainable two wheeler

Item 14: changing lifestyle for sustainability

The analysis of the items that belong to the component 2, show us that this segment not only has a positive view about the sustainability efforts but they have a pretty strong opinion about the efforts that should be taken to improve the current condition of pollution and climate change. These people do not mind sacrificing the economic development for a better greener planet. These people not just have the attitude but also the behavioral aspects which moves them towards opting a more ecofriendly and sustainable two wheeler. We can call this segment of consumers "Active

\section{Sustainable"}

Component 3: This component has high Pearson correlation with item number 13 and moderate correlation with item 15. The description of these items is as follows:

Item 13: hedonistic attitude with respect to sustainability

Item 15: Knowledge about sustainability

This component does not really bother about the negative effects of climate change and pollution caused by usage of fossil fuels. They are more concentrated towards satisfying there needs and wants that make them happy even if has a negative effect on the environment. This segment of consumers can be called "Indulgers/ Sustainability Ignorers "Other than the 3 segments that were identified, we were also able to identify certain factors that make the "active sustainable" more prone to purchasing a sustainable fuel efficient two wheeler. These factors were:

Over all positive attitude towards sustainability

a) Prioritizing environment protection over economic development

b) Readiness to change current life style.

The identification of these three factors also support the three hypotheses that were proposed at the start of this study.

\section{CONCLUSION AND RECOMMENDATIONS}

Based on the results obtained from the Chi square tests the null hypotheses gets rejected for the three hypotheses that were proposed at the start of this paper. Hence there is significant association between: a) attitude towards sustainability and the intention of buying a fuel efficient two wheeler, b) individual's perspective of the climate vs economic development debate and the intention of buying a fuel efficient or a sustainable two wheeler, c) willingness to change lifestyle for protecting environment and intention of buying a fuel efficient or a sustainable two wheeler. The study led to identification 3 types of consumers of two wheelers in India, when we take into account the attitude of the consumers towards sustainability. These segments were named as "Wannabe sustainable", "Active Sustainable", and "Sustainability Ignorers". The first hypotheses that was formulated at the start of the research was tested and it was found that the attitude towards sustainability does affect the intention of the consumer to purchase a fuel efficient vehicle. It was observed that in the consumer segment that were identified as Active Sustainable are really inclined towards purchasing a fuel efficient two wheeler, but another segment named as Wannabe Sustainable who also have a positive attitude towards sustainability are not inclined towards purchasing a fuel efficient sustainable two wheeler. When the "Active sustainable" segment was further analyzed, it allowed us to notice the various factors that make this segment. It was evident that individuals in this segment would prioritize environmental protection over economic development and are ready to make changes in their lifestyle if it can help to preserve the environment. 
This difference that was observed, supports the second and third hypotheses that these factors, which include aspects on prioritizing environment over economic development and readiness to change lifestyle make this segment depict a behavior of acting sustainably for the purchase decision of a two wheeler in mind. One more segment of consumers were identified, who were named the Sustainability ignores. For the further research the factors that differentiate the Active Sustainable from the Wannabe sustainable can be studied. This study will be important because with increase in awareness and information about the ill effects of pollution and climate change, the consumer segment that has an attitude of sustainability is growing each day. It is important that the marketers take a note of this trend and design a suitable strategy for marketing and product development in the two wheelers market in India. Further to this research can also be carried out to identify the sustainability attitude of the rural consumers of India as they are the largest consumers of two wheelers in India.

\section{REFERENCES:}

1. Ajzen, I., \& Fishbein, M. "Understanding attitudes and predicting social behavior",1980.

2. Bieak Kreidler, N., \& Joseph-Mathews, S, "How green should you go? Understanding the role of green atmospherics in service environment evaluations", International Journal of Culture, Tourism and Hospitality Research,3(3), 2009 ,228-245.

3. Chakrabarti, S., "Factors influencing organic food purchase in India-expert survey insights", British food journal, 112(8), 2010, 902-915.

4. Chan, H. K., Yee, R. W., Dai, J., \& Lim, M. K., "The moderating effect of environmental dynamism on green product innovation and performance", International Journal of Production Economics, 181, 2016, 384-391.

5. Cohen, J. "Statistical power analysis for the behavioral sciences (2'EU.)", HillsUale, NJ: Lawrence Eribaum Associates, 1988.

6. de Medeiros, J. F., \& Ribeiro, J. L. D, "Market success factors of sustainable products" Independent Journal of Management \& Production, 4(1), 2013, 188-207.

7. DiStefano, C., \& Hess, B., "Using confirmatory factor analysis for construct validation: An empirical review" Journal of Psychoeducational Assessment, 23(3), 2005, 225-241.

8. Doval.

,https://timesofindia.indiatimes.com/auto/bikes/india-isnow-worlds-biggest-2-wheelermarket/articleshow/58555735.cms, 2017

9. Fishbein, M., \& Ajzen, I., "Belief, attitude, and behavior: An introduction to theory and research". Reading, Mass.: Addison Wessley, 1975

10. Fitzmaurice, J. "Incorporating consumers' motivations into the theory of reasoned action." Psychology \& Marketing, 22(11),2005, 911-929.

11. French, S., \& Rogers, G. "Understanding the LOHAS consumer: The rise of ethical consumerism" LOHAS Journal, 2006.

12. Gadenne, D., Sharma, B., Kerr, D., \& Smith, T, “The influence of consumers' environmental beliefs and attitudes on energy saving behaviours". Energy policy, 39(12), 2011, 7684-7694.

13. Gurău, C., \& Ranchhod, A., "International green marketing: a comparative study of British and Romanian firms", International marketing review, 22(5), 2005, 547 561.

14. Hansen, M. G., "Environmental engagement and product knowledge among consumers of electric light bulbs in Albany, California", published in ES196 May, 2009, 112.

15. India-ranks-177-out-of-180-in-environmentalperformance-indexfrom https://www.thehindu.com/scitech/energy-and-environment/india-ranks-177-out-of180-in-environmental-performanceindex/article22513016.ece, January 2018

16. Juyal, S. A., "Effect of demographic factors on consumer buying behaviour of durable goods", Indian Journal of Marketing, 43(12), 2013, 24-33.

17. Kreeb, M., Motzer, M., \& Schulz, W. F., "LOHAS als Trendsetter für das Nachhaltigkeitsmarketing. Medialisierung der Nachhaltigkeit-Das Forschungsprojekt balance [f]: Emotionen und Ecotainment in den Massenmedien. Marburg", Metropolis, 2008, 303-314.

18. Kumar, P., \& Ghodeswar, B. M., "Factors affecting consumers' green product purchase decisions", Marketing Intelligence \& Planning, 33(3), 2015, 330-347.

19. Lee, K. , "Gender differences in Hong Kong adolescent consumers' green purchasing behavior", Journal of consumer marketing, 26(2), 2009, 87-96.

20. MECA , "Emission Control of Two- and Three-Wheel Vehicles", Manufacturers of Emission Controls Association, 2014,

21. http://www.meca.org/resources/Motorcycle_whitepaper_ update_0914.pdf

22. Mundu, R., Trivedi, H., \& Kurade, Y., "Analysis of factors influencing two wheeler purchases by women", Beacon: Management Review, 2000.

23. Natural Marketing Institute (NMI), "Understanding the LOHAS Market TM; Report" Natural Marketing Institute: Harleysville, PA, USA, 2008

24. http://www.lohas.se/wpcontent/uploads/2015/07/Understanding-the-LOHASConsumer-11_LOHAS_Whole_Foods_Version.pdf

25. Peattie, K., \& Crane, A, "Green marketing: legend, myth, farce or prophesy?", Qualitative market research: an international journal, 8(4), 2005, 357-370.

26. Ramayah, T., Lee, J. W. C., \& Mohamad, O., "Green product purchase intention: Some insights from a developing country "Resources, conservation and recycling, 54(12), 2010, 1419-1427.

27. Singh, G. "Green: the new colour of marketing in India.", ASCI Journal of Management, 42(2), 2013, 5272.

28. Uusitalo, O., \& Oksanen, R., "Ethical consumerism: a view from Finland", International journal of consumer studies, 28(3), 2004, 214-221.

29. Wang, Y., \& Hazen, B. T., "Consumer product knowledge and intention to purchase remanufactured products", International Journal of Production Economics, 181, 2016, 460-469.

30. Xu, L., Prybutok, V., \& Blankson, C., "An environmental awareness purchasing intention model", Industrial Management \& Data Systems, 119(2),2019, 367-381. 


\section{AUTHORS PROFILE}

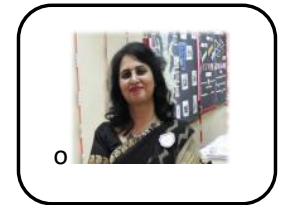

First Author: Dr Ruby S Chanda

Dr Ruby S Chanda is Associate Professor with SIMS. She is B. Sc, B.Ed and MBA in Marketing area. She has done her PhD in the area Customer Relationship Management Her research areas are CRM, Services Marketing and Brand Management and has published around 35 research

papers in National and International Journals. She has Corporate exposure in mainly service industry for around 6 years and was associated

with companies like TATA, Cipla and GTC group handling customer relations and Hard core sales managing sales team for region. Core competency in market research and market survey for developing research reports and developing competitive advantage for clients like TATA Reliance, HDFC . JP Morgan, Whirlpool etc to name a few.She has trained retail and Banking sales staff for customer service and feedback. She has expertise in Sales \& Marketing, Soft Skill and Leadership Module development and training for different sectors at various levels.

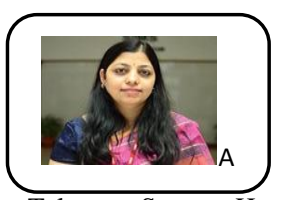

Second Author: Dr Vanishree Pabalkar

Dr Vanishree Pabalkar is an Assistant Professor with SIMS. She is B Sc, MBA, MBS in the field of Marketing. Her PhD was in the area of

Telecom Sector. Her areas of interest are Marketing Management, Business to Business Marketing, Services Marketing and Cases in Marketing. She has published research papers in several National and International Conferences. She has also published research papers in repute journals. She has also published book on Marketing Research. She has corporate experience of 4 years in Service sectors with organizations like ITC, and VSNL. She has also been part of Management Development Programs and Trainings in the field of Marketing.

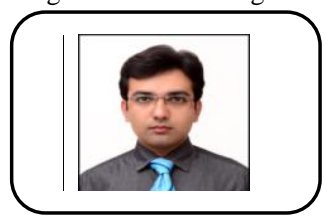

\section{Third Author: Mr Tushar Mishra}

Mr Tushar Mishra is a research scholar at Symbiosis Institute of Management Studies. He has been actively participating in various B school competitions, case studies and has won many awards while studying. He has cleared NET exam. He has been very active in taking part in class and group activities and has demonstrated herself as a good team player. A very diligent student, willing to pursue his career goals with high inclination on research and other allied areas. He was honored with the Faculty award during his tenure while in the Institute. The honor was received during the awards ceremony conducted in the Institute. Currently he is associated with a Corporate. 